\author{
Alleid Ribeiro Machado
}

Universidade Presbiteriana Mackenzie, São Paulo, SP, Brasil

\title{
Mulheres da expansão portuguesa: histórias de (in)submissão
}

Resumo: Neste artigo, analisamos o romance Da Índia, com amor, de Júlia Nery. Para tanto, justifica-se a inserção da autora dentro do cânone do romance histórico contemporâneo português, conforme as definições de Miguel REAL (2012). A seguir, elencam-se algumas relações entre as nações pós-colonizadas, bem como os pressupostos imperialistas ligados às nações ocidentais, de acordo com os estudos culturais defendidos por Edward SAID (2003). A ideia central é mostrarmos como a autora, dentro de seu projeto de reescrita da história, tem dado voz e ação a personagens femininas pouco evidenciadas pela história oficial, ao trazer para primeiro plano a história da aventura de mulheres portuguesas que foram adjuvantes na expansão marítima, mais precisamente, na Carreira da Índia. Contudo, observa-se que o romance apresenta a condição corporal feminina relacionada a outras formas de atuação, ou "moeda de troca" do governo imperialista português, a fim de fortalecer suas relações exteriores. Palavras-chave: romance histórico português contemporâneo; literatura de autoria feminina; expansão marítima; Júlia Nery

\section{O romance histórico português de autoria feminina}

O romance histórico constituiu-se como uma das mais ricas tradições da ficção portuguesa. Para Miguel Real (2012), esse fenômeno deveu-se principalmente pelo desejo de recompreensão e de recentramento da identidade nacional, num período marcado pela perda do Império. Para o autor, o "romance histórico ressurgiu com fortíssima pujança desde 1984, após a utilização propagandística do romance histórico por via de uma atmosfera ideológica de exaltação nacionalista durante o Estado Novo" (REAL, 2012, p. 199).

Contemporaneamente, este gênero tem servido para reabilitar a própria história portuguesa, configurando-se como importante contribuição social. Em consonância ao desejo de revisitação do passado, conforme os pressupostos da vaga da Nova História, ${ }^{1}$

\section{(c) (i)}

Esta obra está sob licença Creative Commons. 
esse tipo de produção tem deitado o seu olhar na história dos que estiveram à margem da história oficial, dos anônimos que constituíram as sociedades, tanto do passado mais longínquo, como do passado mais recente.

Não é por outra razão que o romance histórico contemporâneo vem acompanhando os rastros de pessoas comuns que para longe ou perto partiram, registrando, muitas vezes, os sentimentos de mal-estar ${ }^{2}$ daquelas que estiveram à mercê de novas terras e de gentes de cores e temperaturas tão distintas. Para além da cronologia dos fatos registrados pela história oficial, temos observado um especial interesse dos autores contemporâneos pelos "anônimos" que partiram ou regressaram, enriquecendo-se desses casos e deles tirando o caldo para a invenção de histórias de gentes que, tanto ontem quanto hoje, estão ou estiveram na fronteira entre o seu país de origem e o novo.

A literatura de autoria feminina, como expressão da própria história das mulheres ao longo dos tempos, vem trilhando esse mesmo caminho, de modo que, não raro, encontramos autoras interessadas no resgate historiográfico de personagens femininas em diversas esferas. Nesse sentido, um traço comum dessa literatura seria incutir nos textos demandas de caráter universal que, ao fim, dizem respeito ao feminino e às questões de gênero.

Um desses casos relaciona-se à produção literária de Júlia Nery, cujo romance histórico tem servido não apenas para uma volta ao passado, mas como terreno para profícua disseminação de ideias e retratos da condição feminina, além de suscitar debates em torno de questões feministas e de gênero. A despeito disso, Miguel Real (2012) situa a produção ficcional de caráter histórico da autora portuguesa num tipo de romance histórico que denomina "romance de análise histórico-político-social, o qual procura evidenciar o passado segundo a atual interpretação dos documentos" (p. 223).

Acrescentamos a esta importante consideração o fato de que o tratamento do passado histórico levado a efeito por Júlia Nery é, também, sem dúvida alguma, uma retomada subliminarmente transgressora, sem necessariamente comprometer as versões oficiais dos fatos. O que percebemos na escrita da autora é um desejo explícito de trazer a lume uma visão crítica e pouco neutra em torno dos acontecimentos. Nesse caso, vale ressaltar como a autora revisita o passado, trazendo para o centro de sua escrita a história de personagens femininas atuantes, como podemos notar em seu mais recente romance histórico, Da Índia, com amor, publicado em 2012.

\section{Da Índia, com amor: uma história no feminino}

O enredo do romance se passa no século XVI, momento em que Portugal seguia o plano de expandir os seus territórios na África, Ásia e América. Mais precisamente, toma relevo o cenário de guerras constantes no Estado português na Índia, ao lado do novo ambiente de comércio de especiarias que, à parte ao ideal cristão de combater em cruzada, era aquilo que atraía os portugueses ao Índico.

Esse período, fundamental para a constituição da identidade portuguesa, tem início, como é sempre válido lembrar, em 1415, com a conquista de Ceuta, prolongando-se até

\footnotetext{
' Sugerimos a leitura da tese de doutoramento de Alleid R. MACHADO (2011), cujo capítulo III trata mais especificamente das influências da Nova História no romance histórico produzido após a década de 70 do século XX em Portugal.

${ }^{2} O$ termo é tomado neste artigo segundo o pensamento de Edward Said (2003). Para o autor, o mal-estar está associado à condição do exílio, isto é, ele pode ser experimentado por aqueles que estão/estiveram fora de seus lugares de origem. Nesse sentido, eminentemente associada à experiência do degredo está a condição dolorosa e fatídica de se estar e se sentir "fora do lugar", vivenciada pelo sujeito deslocado de sua terra natal - seu berço, sua casa.
} 
meados de 1543. Para Joaquim Veríssimo SERRÃO (1996), a posição geográfica portuguesa foi um fator decisivo para a aventura dos descobrimentos. Além disso, Portugal nunca havia antes se configurado como uma nação marítima, mas tal prática veio a se consolidar, conforme Luiz Geraldo SILVA (2001): "como resultado natural de uma dada situação política e geográfica, na qual um povo inteiro vivia espremido entre a terra dominada pelos castelhanos e o Atlântico, não tendo, portanto, outros horizontes para expandir" (p. 23).

À altura da narrativa, o caminho das "Índias", como era designada toda a região do Oceano Índico, já estava estabelecido graças a Vasco da Gama que, em 1498, após 10 meses de viagem, aportara em Kappakadavu, próxima a Calicute, no atual estado indiano de Kerala. Temos, então, no romance, uma volta ao passado, mais precisamente localizada num período áureo para a história de Portugal.

No entanto, Da Índia, com amor não será contado sob a óptica dos homens que se destacaram na peleja da conquista do caminho das Índias ou dos que lá se fixaram alguns anos depois, mas a partir da perspectiva de uma mulher. O livro, a versar acerca da empreitada de órfãs portuguesas na Carreira da Índia, ${ }^{3} \mathrm{e}$, depois, do desejo de regresso esboçado pela protagonista Joana, remonta, na verdade, não apenas o momento de conquistas marítimas do império colonial, mas chama a atenção para o fato de que essa faceta da história portuguesa também foi feita por mulheres.

Obviamente, este "retorno ao passado" empreendido por Júlia Nery, compreendido na reescrita desse momento da história de Portugal sob a óptica feminina, implica, necessariamente, sua ressignificação. Do ponto de vista dos estudos culturais, Edward Said (2011), em seu livro Cultura e Imperialismo, ao abordar a questão das relações entre as nações pós-colonizadas, os impérios coloniais e as construções culturais e identitárias nas diversas esferas das artes, lembra-nos que:

A invocação do passado constitui uma das estratégias mais comuns nas interpretações do presente. $O$ que inspira tais apelos não é apenas a divergência quanto ao que ocorreu no passado e o que teria sido esse passado, mas também a incerteza se o passado é de fato passado, morto e enterrado, ou se persiste, mesmo que talvez sob outras formas (p. 29).

O que o autor quer dizer, ao cabo, é que, se, ao menos, não nos é possível compreender inteiramente aquilo que de fato já passou, ainda assim não há nenhuma maneira de isolar o passado do presente. Ambos se modelam mutuamente, um inclui o outro e um coexiste com o outro. Entretanto, trazer para o presente uma história do passado, além de ser uma forma de partilhá-la, é também uma forma de dar a ela um novo significado, pois "do mesmo modo ela também pode ser desfeita e reescrita, sempre com vários silêncios e elisões, sempre com formas impostas e desfiguramentos tolerados" (SAID, 2007, p. 9).

Portanto, a história reescrita por Júlia Nery em Da Índia, com amor é uma história reescrita no feminino. Nela, o leitor descobre-se em meio à partida de uma jovem órfã de nome Joana, que, dentre pouco tempo, questão de algumas horas, deverá embarcar rumo à Índia, seguindo as mesmas pegadas de outras jovens que, no mesmo período, cumpriam igualmente esse destino.

Sinto-me como papagaio de papel e cana, sujeito ao capricho do vento para voar e sustentado no voo pelos cordéis que outros puxam e governam. Na esperança de ganhar paciência para suportar o futuro que me destinaram ou força para Ihe fugir, a

\footnotetext{
${ }^{3}$ Entende-se por Carreira da Índia "a travessia marítima entre Lisboa e Goa, e no sentido inverso, instituída com uma regularidade anual logo após a viagem de abertura da rota e ligação desses pontos por Vasco da Gama em 1497-1499" Cf.: Francisco Contente DOMINGUES e Inácio GUERREIRO (1988).
} 
mim me digo que, depois de tantas voltas de mar, chegará a hora de meu novo nascimento. Sim, tem de ser como se eu nascesse outra vez. Lá, onde me esperam [...] Cai agora a sombra sobre as ondas. Alongo o olhar. Água. Água por todos os lados. $\mathrm{O}$ navio é uma ilha onde eu habito. Daqui para diante o mundo será só água? A monotonia infinita do mar? [...] Quando me vi engaiolada com as outras num pequeno camarote de popa, dispondo apenas de uma varanda para poucos passos de uma curta liberdade, lancei-me a chorar nos braços de Violante, a outra órfã que também ia para a Índia com a família do juiz, nomeado vedor da Fazenda de Goa. As meninas dele, julgandose destinadas a mais amplo espaço por serem filhas de quem eram, postaram-se à varanda, tirando grande prazer do que dali viam (NERY, 2012, p. 10-13).

O excerto acima evidencia exatamente qual mulher Júlia Nery escolhera para ser a protagonista da narrativa: uma que poderia estar, ao menos, oficialmente, a bordo de um navio rumo à Índia. Nesse sentido, ainda observando o relato em pauta, para além de podermos depreender do discurso de Joana o fato de que as meninas órfãs tinham um destino alheio às suas vontades, devemos destacar a seletividade na embarcação de mulheres na carreira expansionista. Nem todas que assim o desejassem poderiam seguir para as possessões marítimas, até porque isso não era uma simples questão de escolha. No caso de uma órfã como Joana, por exemplo, definitivamente não o era também. Havia, antes, vários pressupostos régios, patriarcais, religiosos, a gerir tal possibilidade.

Amélia POLÓNIA (2002), ao realizar um estudo acerca da participação das mulheres na expansão marítima, evidencia que:

Entre essas mulheres, uma distinção clara se impõe entre aquelas que partem com consentimento do poder régio, ou mesmo impulsionadas por ele, $[. .$.$] e aquelas que o$ fazem clandestinamente. Em qualquer caso, e por princípio, a presença de qualquer mulher nas embarcações que cruzavam os mares em direção à África, Oriente ou Brasil era, por norma instituída desde os primórdios da expansão, proibida e fortemente punida. Com efeito, o embarque de mulheres nas naus da Índia, aquelas de que temos mais notícias, era sujeito à condenação civil [...], e religiosa, por parte de bispos e missionários, em particular jesuítas, que com elas contactavam no decurso das viagens (p. 107)

No caso de Joana, ou mesmo de Violante, ${ }^{4}$ a prerrogativa para deixarem Portugal seria o fato de elas serem órfãs. De fato, elas foram obrigadas a deixar o seu país e partir para a Índia, onde encontrariam um lar provisório até o momento de seus casamentos, cumprindo, assim, uma parte da política expansionista. Segundo Maurício de Sousa LINO (2015, p. 146), em 1543, na cidade de Lisboa, fora criado pelo então rei D. João III o Recolhimento das órfãs honradas desta cidade, instituição cujo objetivo era acomodar meninas "virtuosas" e "ilustres", nobres ou pobres, para casamentos nas possessões ultramarinas portuguesas.

Supostamente, elas eram recolhidas por ordem do rei, como parte dos "esforços" de Portugal no processo de colonização. Contudo, um dos escopos finais dessa política era, afinal, o povoamento das terras ultramarinas com a aculturação portuguesa, uma vez que deveriam se casar com governantes nativos ou colonos portugueses. Ao cabo, funcionavam como moeda de troca do Império Português que, em contrapartida, disseminaria a cultura portuguesa para além mar.

Portanto, a estas mulheres portuguesas jovens, brancas, órfãs e de condição social mais abastada fora dada a permissão de embarcar para territórios portugueses fora dos

${ }^{4}$ Violante é uma personagem histórica, enquanto que Joana não. Como o romance procura mostrar, em conformidade com a história oficial, Violante se casou em Goa com D. Diogo de Meneses, filho de Henrique de Meneses, que fora capitão de Goa e governador da Índia. 
limites de Portugal. Acerca dessa prática, como se pode notar no seguinte trecho retirado do livro Histórias das crianças no Brasil, sabemos que:

Dada a falta de mulheres brancas nas possessões portuguesas, a Coroa procurou reunir meninas de "14 a 30 anos" nos orfanatos de Lisboa e Porto, a fim de enviá-las sobretudo à Índia [...]. O maior contingente anual de órfãs do rei enviado às possessões ultramarinas teria sido no ano de 1560 , de cinquenta e quatro mulheres, sendo sua maior parte constituída provavelmente por meninas (Fábio Pestana RAMOS, 2010, p. 36-38).

No entanto, vale ressaltar que distintas realidades se configuram quando abordamos esse contexto. O destino das mulheres na expansão portuguesa estaria implicado aos locais para onde poderiam ser enviadas. Para Amélia Polónia (2002), a distância, os objetivos políticos e econômicos a atingir, ou, mesmo, as condições climáticas e de salubridade interferiam de forma determinante nas estratégias seguidas e nas tendências definidas.

\begin{abstract}
Assim, desde o primeiro momento, a presença de mulheres integradas em células familiares e em unidades de produção avulta no Norte de África e na Madeira e Açores, consequente de um processo de emigração familiar que conduzia grupos de agricultores e de oficiais mecânicos, a par dos capitães de praças ou capitães-donatários e dos oficiais administrativos, a ficar-se de forma continuada nesses e paços ultramarinos com as respectivas famílias [...] Já na costa ocidental africana a realidade revelou-se bem diversa. O peso considerável da população negra e, em particular, o clima e as doenças tropicais desenvolveram uma ficção de longo curso e, mais ainda, a emigração familiar. Também para o Brasil são conhecidos numerosos casos de emigração de famílias envolvidas quer na colonização económica [...] quer na gestão administrativa, sendo, reconhecidamente desde finais do século XVI e meados do século XVII, incentivada a emigração livre de casais dos arquipélagos da Madeira e dos Açores para o Brasil. [...]. No espaço do Oriente Índico [...] são promovidos pela Coroa os casamentos com mulheres enviadas do reino [...] pelo que a presença da mulher portuguesa se revela de igual modo notória, maioritariamente em Goa e em outros núcleos urbanos de significado. Não poderemos ainda esquecer a emigração familiar forçada, aquela que conduz ao degredo, ou à fuga de cristãos-novos e ciganos, cujas famílias se constituem em colonizadores dos novos territórios [...] (p. 112).
\end{abstract}

Ao lado dessas questões, a escolha de Júlia Nery por uma protagonista que poderíamos considerar "comum", mas que possuía um papel dentro da políica expansionista liga-se, na verdade, a um projeto literário, como procuramos expor brevemente no início deste artigo. A crítica portuguesa Cristina Maria da Costa VIEIRA (2002), em seu livro O universo feminino n'a Esmeralda partida de Fernando Campos, ao discutir os tipos de romances históricos elaborados desde Walter Scott, salienta que, para longe do romance histórico tradicional, cuja visão era baseada em personagens ilustres, fatos e datas, o romance histórico pósmoderno, em consonância com os pressupostos da Nova História, tende tematicamente a revisitar historiograficamente as mulheres enquanto sujeitos da história.

Segundo Vieira (2002), isso ocorre em consequência da luta contra uma concepção da história oficial sintetizável no trinômio "datas-reis-batalhas". Existe, portanto, uma forte tendência presente, a exemplo disso, em ensaístas como Georges DUBY e Christiane K. ZUBER (1993) em revisitar a história por meio de homens e mulheres que ocupam o mesmo espaço, pois são analisados os gestos das massas anônimas e não mais as "celebridades" da história oficial.

Joana não é uma personagem histórica, embora esteja inserida num plano de revisitação da história. Ela é uma órfã d'el rei, cujo importante papel durante a expansão marítima portuguesa só muito recentemente tem sido lembrado pelos historiadores, muitos deles ligados ao próprio projeto da Nova História. É justamente sobre essas órfãs, ou seja, 
sobre mulheres de pouca visibilidade, mas que desempenharam uma função tão admirável na época áurea dos descobrimentos, que Júlia Nery lança o seu olhar.

Em Da Índia, com amor, a história ficcional é narrada por Joana, que se vale de suas impressões pessoais em torno da viagem e da nova terra, para dar-nos a conhecer um pouco acerca de sua vida. A órfã segue na Carreira da Índia, deixando para trás um amor de infância: "Ah, como eu desejaria, meu amado, estarem aqui teus olhos e ouvidos" (NERY, 2012, p. 59); levando consigo alguns bens, como joias de família, e as saudades de sua terra, "saudade de tudo o que deixei para trás" (NERY, 2012, p. 48). As impressões de viagem se fazem logo no embarque, quando se vê diante de um destino alheio à sua vontade: "Assim foi nos dias de minhas saídas, sendo já órfã de pai e mãe, primeiro para a caridade dos meus parentes em Lamarosa, de lá para o recolhimento das órfãs d'el rei e daí para esta nau que me leva à Índia" (NERY, 2012, p. 10).

O início da viagem é marcado pela tristeza da partida ao lado da curiosidade de ir habitar o outro lado do mundo, como lhe contavam ser a Índia. A órfã seguirá a viagem trazendo consigo a única certeza de quem era "sei quem sou" (NERY, 2012, p. 14), embora temesse perder sua identidade na nova terra, segundo o que Ihe sugeria sua companheira de condição e viagem, Violante. Joana, ou, mesmo, Violante, como órfãs d'el rei, teriam dote e destino desdobrados numa outra terra sem poder de escolha.

As grandes diferenças desta cidade com Lisboa são os cheiros e as gentes que andam pelas ruas. Vi muitos de pele escura, alguns nus, quase todos mal vestidos; os homens de tez branca aqui usam todos espada e a maior parte se veste de seda. Num momento em que os carregadores tiveram de parar [...] passaram rentes ao palanquim uns homenzinhos de rosto amarelo e de olhos tortos. Chineses, disseram-me depois. 0 parecer dos mouros e negros era igual aos que vira em Lisboa, mas o dos mestiços parecia-me diferente (NERY, 2012, p. 50).

As impressões de Joana dão-nos a medida do contexto multicultural que abrangia a colonização portuguesa, que, para além do controle de seus territórios, estabelecimentos comerciais e militares, bens e interesses, visava ao estabelecimento de relações com vários e diversos tipos de pessoas, de diferentes procedências, religióes e costumes. Joana aprenderá a adaptar-se àquela nova realidade. Sua identidade será moldada por aquele novo estado de coisas, de modo a ter que, muitas vezes, abrir mão ou, mesmo, questionar as bases morais e religiosas de sua educação.

Em seu livro Orientalismo, originalmente lançado em 1978, Edward Said, ao questionar os modos pelos quais os pressupostos imperialistas se relacionam às culturas ocidentais, principalmente nos processos de descolonização, lembra-nos que o Oriente tem sido um locus para a construção da alteridade. Isso se deve ao fato, segundo o autor, de as nações colonizadoras terem constituído suas identidades na distinção do que seria o "nós" em oposição ao que representariam "os outros".

Said retoma essa dicotomia no livro que vai publicar em 1993, intitulado Cultura e Imperialismo. Nesse sentido, para ele, o Oriente é praticamente uma "invenção europeia" e fora, desde a Antiguidade, "um lugar de episódios romanescos, seres exóticos, lembranças e paisagens encantadas, experiências extraordinárias" (SAID, 2007, p. 22). No entanto,

o Oriente não é apenas adjacente à Europa; é também o lugar das maiores, mais ricas e mais antigas colônias europeias, a fonte de suas civilizações e línguas, seu rival cultural e uma de suas imagens mais profundas e mais recorrentes do Outro (SAID, 2007, p. 22).

Temos, assim, que a revisitação do passado feita por Júlia Nery também implica a revisitação das relações entre Portugal e os territórios colonizados na Ásia, representados, mais especificamente no romance, pelo estado de Goa. Da Índia, com amor procura 
evidenciar o fato de que essa possessão não era formada por tribos incivilizadas e bárbaras, muito pelo contrário. As páginas do romance permitem-nos um mergulho nas raízes culturais e nas tradições de uma comunidade que lograva, realmente, uma longa história de grandeza e tradição desenvolvidas. Tal fato, que impôs limites à intervenção dos portugueses na imposição de seus costumes, resultou, por outro lado, na hibridização das relações entre colonizador e colonizado. Talvez seja este um dos grandes triunfos do romance: dar-nos uma amostra da hibridização cultural e da fusão dos costumes, num jogo de espelhos a refletir imagens confrontadas do "eu" (o império dominante) e do "outro" (a possessão portuguesa).

Nesse âmbito, a seguir, citaremos alguns excertos do romance Da Índia, com amor, a fim de contextualizarmos as próximas reflexões.

(1)

Desde menina minha mãe ensinou-me, no bordar, a paciência; minha avó, nos preceitos da lei de Deus, a fé. No convento para onde me levaram a mando d'el rei antes de vir para a Índia, ensinaram-me o que julgavam bom para ser esposa perfeita (NERY, 2012, p. 123).

(2)

Ajoelhei-me ao lado na selha onde Gaspar se sentava, enfeitei a água com as flores, perfumei-a. Quando Gaspar se soergueu para me fazer levantar, Jaoá, movendo suas mãos num bailado triunfante, foi saindo do aposento às arrecuas, apontando para um prato de prata com incenso, cinco espécies diferentes de areca, noz-moscada e dinheiro. Imitei o bailado das mãos de Jaoá sobre o corpo de meu marido. O aposento ia sendo invadido por uma névoa de vapores saídos da água do banho, envolvendo-me com estranhos odores e tonturas de sonolência. Tenho ainda memória da leveza impossível do incenso, do dinheiro que derramei sobre meu marido, de o massajar com vatame, do seu corpo pesado, escorregadio e perfumado. De mais nada [...]. Os rituais do Diwali são nesta terra atos gratos aos olhos dos seus deuses. Eu, cristã, sei-o, não saí sem pecado da festa das luzes, sagrada para os hindus e para mim a celebração de meus sentidos todos. Se por ela fizer penitência, não é a do arrependimento (NERY, 2012, p. 128).

(3)

Xandru era esposa de um homem de Goa com quem meu marido negociava, louvandoIhe a sabedoria e a posse de boas mercadorias, para ambos motivo de rendosos lucros. Ainda que nós as mulheres reinóis pouco privássemos com as hindus, tinha eu algumas vezes sido convidada por ela para the falar dos costumes do nosso reino e religião, mostrando-se muito mais atenta a eles do que se fosse apenas por curiosidade [...]. Assim, sendo nós da mesma idade, o que aprendi ser melhor razão de entendimento que raça, género ou estado, ambas nos podíamos entreter em longas conversas. Com ela aprendo coisas sobre as gentes destas terras, que eram para mim maravilha de novidade. Foi Xandru quem me mostrou pinturas em seda [...]. Explicava-as de maneira a dar-me muita vergonha e a ela prazer, pois foi educada a ver em tais representações do amor coisas amáveis para sua felicidade e não armas do demónio para comprar nossa alma, dando-nos por ela as penas do inferno (NERY, 2012, p. 160).

Os três trechos de Da Índia, com amor evidenciam, num primeiro plano, a educação que Joana recebera ainda em Portugal, tanto das mulheres com quem vivera na infância, representadas pela mãe e pela avó, quanto da educação conventual; além da tentativa de Joana, num segundo plano, de apropriação dos costumes das mulheres gentis de Goa. O terceiro trecho em pauta também nos oferece uma amostra da convivência entre as mulheres europeias e as hindus: se, de um lado, Xandru se mostrava maravilhada pelas tradições dos ocidentais descritas por Joana, esta passou a entender como as mulheres hindus, representadas por Xandru, tiveram uma educação amorosa muito mais libertária, se comparada à sua e de suas contemporâneas portuguesas. 
Após dois anos em Goa, Joana já dá mostras da assimilação de alguns costumes locais e do confrontamento de algumas práticas das mulheres indianas, sobretudo relacionadas aos rituais de sedução das mulheres gentis sobre os homens, em oposição aos rígidos preceitos morais e religiosos que ela, como mulher ocidental e cristã, também recebera.

Os excertos em destaque igualmente apontam para um aspecto do cotidiano das mulheres portuguesas nas possessões portuguesas, principalmente no que tange às relações interpessoais. Trata-se, portanto, de outra história. No romance de Júlia Nery, adentramos o universo de mulheres que, com desempenhos muito diversos, atuavam como dilatadoras da cultura, de suas crenças, de seus costumes e como receptoras da cultura local. Atuando no universo privado, doméstico, revelavam-se adjuvantes no processo da hibridização dos costumes.

Para debater a questão das mulheres durante o processo de expansão marítima, é preciso abrir os nossos olhos para diversos aspectos de como ele era constituído. A par da história oficial, o romance de Júlia Nery lembra-nos que as mulheres que partiam, além de serem estratagemas da colonização, funcionando também como garantia de povoamento e colonização em paralelo, garantiam o funcionamento das sociedades, atuando para além dos processos de emigração e de colonização.

Além disso, Da Índia, com amor evidencia o fato de que as mulheres portuguesas estiveram presentes nos espaços ultramarinos desde os primeiros tempos, e que sua presença foi muito mais notória do que a maior parte da história nos faz crer.

A história reescrita pela óptica feminina revela-nos essa faceta apagada da época expansionista, ressaltando a importância das mulheres como reforço do poder colonial. Podemos depreender, portanto, que a narrativa em torno da jovem órfã, que seguiu na diáspora portuguesa, suscita algo que é ancestral na identidade portuguesa: os sentimentos de medo e êxtase pela ânsia de movimento, de procura, pela descoberta do desconhecido. No entanto, Joana não deve se adaptar definitivamente a Goa, que continuará a ser para si um espaço em trânsito, multicultural, estranho.

O sentimento de mal-estar, relacionado ao fato de estar ocupando um local que the é peculiar, faz-se no estranhamento de uma cultura tão diversificada e diferente da sua, gerando nela um sentimento de pertencimento ambíguo, já que sabe que está nos limites do império de seu próprio país. Este movimento dicotômico de "partida e chegada", segundo Carina CERQUEIRA (2009), implica reconhecer a saudade do que ficou para trás e "praticar uma alternância entre espaços, culturas e mentalidades" (p. 1).

Talvez, reforçada por esse sentimento, Joana será capaz de um grande ato de insubmissão para se livrar da tutela de seu marido, a quem não ama, e seguir atrás de seu maior sonho: retornar a Portugal. Entretanto, a torna-viagem ${ }^{5}$ era algo impossível de acontecer para uma mulher, a menos que isso fosse a vontade de seu esposo, ou de outra figura masculina que exercesse o poder de tutor e responsável: "Um homem irá aonde quiser, não uma mulher que arrisca ser desembarcada, mandada de volta [...], e mesmo ser açoitada à vista de toda a gente" (NERY, 2012, p. 142).

Frustrada por ter perdido o seu grande amor de infância, que, chegado à Índia, é submetido a um casamento por conveniência com uma mulher hindu, decide partilhar tal quimera com a amiga Leonor de Sá, ${ }^{6}$ que dividia consigo o mesmo objetivo. Assim, a

\footnotetext{
${ }^{5}$ Acerca dos problemas enfrentados por aqueles que desejavam retornar ao reino, ver o trabalho de Rui Alexandre Landeiro GODINHO (2005).

${ }^{\circ}$ O nome de Leonor de Sá emerge na história oficial porque fora esposa de Manuel de Sousa Sepúlveda fidalgo e militar português, nascido em 1500, que serviu na Índia a partir de 1534. Em 1552, juntamente com a sua família, naufragou a bordo do galeão São João, perto do Cabo da Boa Esperança. Tal episódio é recuperado no romance Da índia, com amor.
} 
protagonista traça um plano que exige de si a renúncia de sua identidade social em favor de uma nova classe. De fato, Joana já vinha sendo preparada interior e paulatinamente para uma mudança na ordem de sua vida. Durante a sua estada em Goa, a protagonista foi reconhecendo nas amigas nobres portuguesas, ou nas castiças, os mesmos dramas de gênero relacionados à interdição de agir conforme os seus desejos.

Esta vivência foi the proporcionando uma transformação, de modo que Joana passará a relativizar o valor das coisas e dos sentimentos e abandonará a sua atual condição "reinol" em favor de um papel modesto a fim de retornar a Lisboa.

Desta forma, sentiu-se pronta para ser agente de uma nova guinada em seu destino. Joana embarca no porto da cidade de Cochim, localizado na parte ocidental da Índia, no galeão São João, disfarçada de escrava de sua amiga Leonor de Sá. Na pele de uma mulher de condição simples, poderia estar mais próxima da liberdade que sonhava.

\begin{abstract}
Leonor de Sá ri-se dos meus receios para os tornar (SIC) improváveis e dá-me o seu espelho para que uma e outra vez eu me espante com a imagem que ele me devolve. Muito pode a pintura do cabelo e dos olhos, à moda das indianas, mudar o parecer de uma mulher! Violante com suas tintas de ervas tornou mais negro que tição o meu cabelo dourado, praticou comigo gestos de insubmissão, sendo o baixar dos olhos o mais difícil de aprender. Leonor de Sá, embrulhando-me nos vestidos de uma escrava moura e pondo-me os meninos nos braços, conseguiu o milagre de eu passar o alardo sem ser reconhecida (NERY, 2012, p. 213).
\end{abstract}

Joana embarcou no galeão São João, o mesmo que, conforme fontes históricas, como a que encontramos n'A História Trágico-Marítima (1735-1736), de Bernardo Gomes de BRITO (1942), sofreu um naufrágio já muito próximo ao Cabo da Boa Esperança. Segundo o relato de Álvaro Fernandes, possível sobrevivente do galeão, dos náufragos que resistiram ao acidente, sobrou apenas um grupo liderado pelo cunhado de Sepúlveda, Pantaleão de Sá, o qual se sabe ter sido acompanhado no resgate por três escravas, ficando implícito nas linhas finais da narrativa tratar-se ser uma delas a protagonista do romance. Joana teria, então, supostamente, retornado a Goa, mas:

Resgatada por D. Violante de Meneses, acompanhou sua senhora ao reino, quando ela veio na Carreira da Índia com o marido. Este nobre, desfavorecido na corte de D. Manuel, depois de fazer fortuna na Índia obteve a graça da permissão do rei D. João para regressar com sua mulher a Portugal (NERY, 2012, p. 244).

\title{
Considerações finais
}

Como se pôde observar ao longo deste artigo, o romance em pauta traz à tona a história e os feitos de mulheres portuguesas que foram adjuvantes da expansão marítima. Mais precisamente, por meio de Joana, retoma as aventuras das órfãs d'el rei, jovens que eram enviadas para as possessões ultramarinas como estratagemas da política matrimonial e de povoamento ocidental das colônias.

Nem sempre um fato é espelho para refletir a verdade sem nuances. Os fatos se constroem também numa dinâmica enviesada, numa estrada de muitas vertentes. É comum olharmos para um acontecimento histórico nos esquecendo de que sobre ele pode haver muitas versões e interpretações. Ao conhecermos essa faceta da história na pele de Joana, acabamos por perceber que o jogo da verdade se relaciona com a forma como os papéis de gênero e, mesmo, os papéis sociais eram construídos e, mais do que isto, burlados.

No caso de Joana, Violante, Leonor de Sá, e de outras mulheres e de outros homens, suas histórias construídas a partir da narração das viagens que empreenderam, dos relatos 
das guerras movidas em Goa, dos naufrágios; nas descrições das festividades hindus, são mais do que meros relatos dos acontecimentos passados. Elas formam um caldo cultural representativo de um período, de uma nação, refletindo no presente a imagem caleidoscópica sob a qual a memória cultural ganha espaço para novas abordagens e redefinições.

As pesquisas em torno da história de pessoas comuns têm demonstrado outras possibilidades de atuação feminina no contexto das navegações portuguesas. Da esfera particular, doméstica como esposa e mãe, notamos que elas se fizeram presentes no esforço de enraizamento nas possessões portuguesas, na tentativa de assimilação ou de costumes locais, dilatando também suas crenças, suas tradições. Nesse sentido, podemos afirmar que Da Índia, com amor, dentre a riqueza e multiplicidade de temas e leituras que sugere, também tem evidenciado essas questões, trazendo a lume tanto os estados de dependência quanto de emancipação feminina.

Criadas em berço patriarcal, não seria demasiado lembrar que a atuação delas estava subordinada aos interesses do Estado, do pai, do esposo. Nesse sentido, à revelia dos interesses do Império, o espaço de atuação feminina variava consideravelmente. O contexto dos descobrimentos gerou uma postura diferenciada por parte dos homens no que tange aos papéis desempenhados pelas mulheres. A partir dessa nova dinâmica, ainda que continuassem a ser consideradas como seres inferiores, a condição corporal relacionada à sua natureza faria com que fossem destinadas a outras formas de atuação, ou moeda de troca dos governos imperialistas, a fim de fortalecer as relações exteriores, como vai ocorrer com as órfãs destinadas ao casamento na Índia. Pelo menos, a análise do romance histórico de Júlia Nery permite-nos essa reflexão.

Certamente, encontramo-nos muito longe das imagens femininas dos quinhentos ou seiscentos em Portugal. E a literatura de autoria feminina, especialmente no que se relaciona ao romance histórico contemporâneo, pode usufruir desse distanciamento para a reescrita de uma nova história. Uma que inclua as nuances ocultas da atuação das mulheres num momento capital para a formação da própria identidade de uma nação. Da índia, com amor carrega consigo este importante mérito.

\section{Agradecimento}

Este artigo é fruto de pesquisa financiada pela Fundação de Amparo à Pesquisa do Estado de São Paulo (FAPESP).

\section{Referências}

BRITO, Bernardo Gomes de. A História Trágico-Marítima (1735-1736). Barcelos: Companhia Editora do Minho, 1942. Disponível em: http://purl.pt/191/4/. Acesso em: 29/04/2015.

CERQUEIRA, Carina. As viagens na obra de José Eduardo Agualusa. Disponível em: http:// www.iscap.ipp.pt/cei/E-REl\%20Site/2Artigos/Artigo\%20Carina\%20Cerqueira.pdf. Acesso em: 03/01/2015

DOMINGUES, Francisco Contente e GUERREIRO, Inácio. "A vida a bordo na Carreira da Índia (século XVI). Revista da Universidade de Coimbra, v. XXXIV, p. 185-225. 1988. Disponível em: http://www.iict.pt/imagens/198.pdf. Acesso em: 21/08/2016.

DUBY, Georges e ZUBER, Christiane K. História das mulheres no ocidente, v. 2. Porto: Edições Afrontamento, 1993.

GODINHO, Rui Alexandre Landeiro. A carreira da Índia, aspectos e problemas da tornaviagem: 1550-1649. Lisboa: Fundação Oriente, 2005.

1138 Estudos Feministas, Florianópolis, 25(3): 1129-1140, setembro-dezembro/2017 
LINO, Maurício de Souza. Os Grumetes da Nau Santa Maria. São Paulo: Clube de Autores, 2015. Disponível em: https://books.google.com.br/books?id=Y†2xDAAAQBAJ\&pg=PA9\&l $\mathrm{pg}=\mathrm{PA} \& \& \mathrm{dq}=$ Os + Grumetes+Da+Nau+Santa+Maria\&source $=$ bl\&ots=SuXyFJmq9h\&sig=ba2 csJYeG_XCRUECOKpTWp79il\&hl=pt-BR\&sa =X\&ved=0ahUKEwjCmvn5xtPOAhWGQZAKHY cyBy|Q6AEIKDAD\# $v=$ onepage \&q=Os\%20Grumetes\%20Da\%20Nau\%2OSanta\%2OMaria\& $\mathrm{f}=$ false. Acesso em 21/08/2016.

NERY, Júlia. Da Índia, com amor. Lisboa: Sextante Editora, 2012.

MACHADO, Alleid R. As personagens femininas de Júlia Nery: paradigmas e representações. 2011. Tese (Doutorado em Letras), FFLCH/ USP, São Paulo.

POLÓNIA, Amélia. "Espaços de inclusão e de exclusão de agentes femininas no processo de expansão ultramarina portuguesa (século XVI)". In: Os espaços femininos no mundo americano. Atas do XIII CONGRESSO INTERNACIONAL DA AHILA. Ponta Delgada, 3-8 de setembro de 2002, p. 107-124.

RAMOS, Fábio Pestana. "A história trágico-marítima das crianças nas embarcações portuguesas do século XVI". In: DEL PRIORE, Mary. Histórias das crianças no Brasil (Org.). 7.ed. São Paulo: Contexto, 2010.

REAL, Miguel. O romance português contemporâneo: 1950-2010. 2.ed. Alfragide: Editorial Caminho, 2012.

SAID, Edward W. Reflexões sobre o exílio e outros ensaios. São Paulo: Companhia das Letras, 2003.

Orientalismo. São Paulo: Companhia das Letras, 2007. E-book. ISBN 9788535910452 Cultura e imperialismo. São Paulo: Companhia das Letras, 2011. E-book. ISBN 9788535919516.

SERRÃO, Joaquim Veríssimo. História de Portugal: a formação do Estado moderno (14151495). 8. ed., v. 2. Lisboa: Editorial Verbo, 1996.

SILVA, Luiz Geraldo. A faina, a festa e o rito: uma etnografia histórica sobre as gentes do mar (sécs. XVII ao XIX). Campinas: Papirus, 2001.

VIEIRA, Maria Cristina da Costa. O universo feminino n'A esmeralda partida de Fernando Campos. Algés: Difel, 2002.

[Recebido em 08/05/2015, reapresentado em 01/09/2016 e aprovado em 15/02/2017]

Women of Overseas Expansion: Histories of (In)Submission

Abstract: In this paper, we analyze the novel Da Índia, com amor, by Julia Nery. Therefore, it is appropriate to insert the author within the canon of contemporary Portuguese historical novel, according to Miguel Real considerations. In the sequel, we list some relationships between postcolonized nations and the imperialist assumptions related to Western nations, according to the cultural studies presented by Edward Said. The central idea is to show how the author, in her rewriting of the history, has given voice and action to female characters, which are somewhat evidenced by official history, by bringing to the fore the history of Portuguese women. They were adjuvants in maritime expansion, more specifically, in the way to India. However, we observe that the novel presents female body condition related to other forms of action, or "bargaining chip" of the imperialist Portuguese government in order to strengthen its foreign affairs.

Keywords: Contemporaneous Portuguese Historical Novel; Literature of Feminine Authorship; Overseas Expansion; Júlia Nery 
Alleid Ribeiro Machado (alleid@usp.br) é mestre e doutora em Letras pela Universidade de São Paulo. Professora na Unisant'anna, pós-doutoranda em Literatura Portuguesa na FFLCH/USP. e bolsista da Fundação de Amparo à Pesquisa do Estado de São Paulo. Suas linhas de pesquisa são: literatura de autoria feminina; narrativa contemporânea; estudos de gênero, corpo e sexualidade. É membro do Grupo de Estudos de Literatura Portuguesa de Autoria Feminina (USP/CNPq) e do Grupo de Investigação das Relações entre Literatura e Jornalismo do Centro de Literaturas e Culturas Lusófonas e Europeias da Universidade de Lisboa.

1140 Estudos Feministas, Florianópolis, 25(3): 1129-1140, setembro-dezembro/2017 